\title{
EFFECT OF TRADING COMPANIES SHARE ON INVESTORS ATTITUDE AND FINANCIAL BEHAVIOR
}

Jawed Baloch, jawedahmed477@gmail.com

Master of Business Administration in Finance, Mehran University Institute of Science \& Technology Development, Mehran University of Engineering \& Technology, Jamshoro, Pakistan

Muhammad Akram, akramalilashari@gmail.com

Master of Business Administration in Finance, Mehran University Institute of Science \& Technology Development, Mehran University of Engineering \& Technology, Jamshoro, Pakistan

Sayed Urooj Fatima, ufatima37@gmail.com

Master of Business Administration in Finance, Mehran University Institute of Science \& Technology Development, Mehran University of Engineering \& Technology, Jamshoro, Pakistan

Shafqat Aman, shafqataman66@gmail.com

Master of Business Administration in Marketing, Sukkur Institute of Business Administration University, Sukkur, Pakistan

\begin{abstract}
Pakistan is under developing country and it has an unpredictable market nature of shareholderinvestors observe the company's performance. This research could help to companies in understanding financial behavior, attitude and investors' satisfaction in stock trade. Financial behavior is comparatively new subject in Pakistan therefore; this study has examined the financial behavior and attitude of investors. The behavioral finance that has been attempted to understand the positive experiences influences investors' financial behavior. This study has find out that investor satisfaction is strongest in influence of positive financial behavior of investor and trader in stock trading; positive experience and brokers suggestions are strengthens the investment decision of investors and increases behavior loyalty to prefer over competitor. The main purpose of research to determine the effect of financial behavior on investors' attitude and behavioral loyalty and investors' satisfaction to preference over competitor. The research framework links with experiences in stock trade for positive (negative) experiences, attitude and financial behavior is developed. The research framework is measured data from sample of Karachi and Karachi Stock Exchange; the data is analyzed in smart PLS based on PLS-SEM. This study focused on trading experience with company's active investors and traders in banking industry in Pakistan. The future research could be research in other sectors with inter-related issue of investors and traders (brokers) in stock trade. This is the first study in this research area; this study will be determine the experiences with positive (negative) financial behavior, attitude, satisfaction and behavioral loyalty of investors and traders in stock trade. Therefore, adding in this area of study which will help understanding the investors and traders attitude, preference and financial behavior in financial market.
\end{abstract}


Keywords - Financial Behavior, Investor Attitudes, Traders and Investors Behavior, Experience, Investment Decision.

\section{Introduction}

Investing with company's stock and expectations of return of investor's is based on their experiences and it is a risky for the investors, through various authors and publishers to finding customer's behavior in a way of negative (positive) experience of the shareholder and customers. The investor's behavior determines the asset price behavior and market behavior, (Ahmad, Ibrahim \&Tuyon, 2017). Hence, it is important to make financial markets operate efficiently by effectively controlling the behavioral biases that causes the anomalies, (Cuthbertson, Nitzsche, \& O'Sullivan, 2016). Further; study shows that behavioral biases are sum of organized problems in understanding and judgments (Pompian, 2006). Though Shefrin describe that bias is not more than inclination towards problem taken by the shareholders towards their investment decision (Shefrin, et al., 1985). According to a study that the behavioral finance distributes with how a behavioral factor creates the differences in term of shareholders' investment process. Further he describe that for a long-term it has been observed that the shareholders think rationally and take a proper and accurate investment decisions based on traditional finance theories. Throughout above statements and other a number of researches suggest that most of investment decisions are taken based on institutions emotions and cognitive biases on trading of stock in market.

The recent study where evidence show that investors who invest for their own selves give a greater preference to seeking guidance from experts (Asad Humaira, et al., 2018). In the context of Pakistan, where most of the investors take decisions on the basis of their institutions rather than relying on the information available from different sources, (Shahid M. Naeem, et al., 2018). The study from Bangladesh have found that relationship between the affecting factors and investment decisions, the factors which including risk taking, political, return earning, etc. these factors are damaging and de-motivating the investors decisions in stock trading (Surajit S. et al., 2018).

It is more important to understand the investor's behavior and attitude while they have taking decision to invest in the same company or moving to another in stock market. As per Mark KY Mak, et al., they have stated about investment behavior or preference over companies. They have described few factors of investment behavior which investor's psychological, sociological and demographical factors are significant predictors of their investment behavior or preference (Mark K.Y.M, et al., 2017). According to Statman, that expected returns follow behavioral asset pricing theory, where risk is not measured and expected returns are determined by more than risk. And behavioral finance explains about why and how emotions and cognitive biases create risks about stock market for investors, (Asab M. Zulqarnain, et al., 2014). As per another author from Pakistan stated that psychological factors have dominating influence upon the decision of the investors, (Islam, 2012). Adding more about the factors of psychological, he described some factors like cognitive dissonance, regret aversion, gamblers fallacy and etc.

In this study we analyze the investor's positive and negative financial behavior towards company's share bring on by performance of stock preference over investor investment behavior in favor of behavior loyalty and investor satisfaction closer to stock performance; referring firm to new investors, making advices for others in investment decision. In the perspective of 
shareholder and investors who want to support and help in growth of the company; they invest their capital. The investing in the support of the company which means the shareholders become customers of the company, during repurchasing of shares the company focus on their attitudes and purchasing behavior regarding help of company. Aspara (2009) who investigate that investors who invest in by purchasing company's products (stocks) and services in terms of support to the company.

According to Sing-Yang Hu (1997), in an Amihud-Mendelson type of model, assets have different transaction costs and investors have different trading frequencies. Investor's decision is to choose assets to hold to maximize their net holding returns. In equilibrium, investors with higher trading frequencies will hold assets that have lower transaction costs and therefore obtain lower gross expected returns (Sing-Yang Hu, 1997).

Researchers in behavioral finance have expended considerable effort in trying to understand investment decisions. Decision making behavior of the brokers involved in the financial markets, particularly the institutional investors who has account for the bulk of the activity (Gabaix et al., 2006; Gompers and Metrick, 2001). In the finance and marketing interface, has investigated the effect of brands and brand variables in investment choices and decisions, both for individual and institutional investors (Frieder et al. 2005; Huberman, 2001; Keloharju et al. 2012). The traditional financial behavior literature assumes that making investment choices, investors want to maximize their expected return for the given level of risk given all market information (Clark M. et al., 2004). However, in this type of rational agent model is challenged by the psychological views that individuals' behavior are influenced by the interactions of perceptions and expectations, motives, attitudes and affect.

The enough confirmation of shareholders-customers; they have long-term relationships with companies are mostly like to purchase company's share and becomes long-term investors (Keloharju et al., 2012). Adding on this regard, Strahilevitz stated that past experiences of investor has influenced the investment decisions and choices of stock trading in market. Traders and shareholders, who frequently fit to re-purchase of stock and sold for profit than the stock sold for loss. The negative emotions are increases by selling of underperforming stock of company. The disappointment induced by selling stock in loss in past and getting negative emotions and experiences; losing investment by selling stock is loss. Accordance of researchers that selling of stock in losing investment makes a real loss (Fogel, et al., 2006; Strahilevitz, et al, 2011 and Summers, et al, 2012).

Pakistan recently developing strategy for getting attention of investors thought stock market where external investors to trade and invest their capital in Pakistan throughout shares of different companies in Pakistan (Asad Humaira, et al. 2018). According to a study behavioral finance claims that investors are normal behavior during purchasing of shares from market, although researchers investigate that shareholders and traders may not behave reasonably during their investment decision making (Babajide, et al. 2012). From all decision of Pakistan, investors' behavior would be grace in terms of investment purpose. Thus the current study of author and examined the impact behavioral on investors' decisions at Pakistan Stock Exchange and this research would be helpful for investors and traders to take reasonable decisions and able to analyze stock market trends while they have taking decision for investment (Shahid M. Naeem, 2018). 


\section{Literature Review}

A sufficient literature determines and addresses about investors holding in stock trade and their negative (positive) experiences based on purchasing behavior and attitudes in trading of shares. A lot of literature available on financial behavior, shareholders loyalty investment satisfaction and investors' behavior loyalty in trading of stock, but less observed in Pakistan to examine the financial behavior of shareholders, brokers and traders while taking decisions of investment in stock market, here are some contributions of authors in literature from different perspectives.

Lanlan C. et al. (2018), in trading of shares and stock market responds actively and positively to mobile app addition this is why technology innovating day by day and development of technology help the investors who understand the trend of market. While the many literatures suggest that mobile app additions carry benefits and threats in market, and it has shown that the benefits outweigh the threats from an investor's perspective.

Asad Humaira, et al. (2018), technology plays an important role but investors also prefer suggestions and advise from experienced person. The sufficient evidence to show that investors who are investing for their own selves give a greater preference to seeking guidance from the expert.

Shahid M. N. et al. (2018), described that the investment decisions of the majority of the investors at Pakistan's Stock Exchange have been influenced by their behavioral biases.

Surajit S. et al. (2018), the study has been done in Bangladesh and author recommend in literature that many of influencing factors which these factors significantly effective on investment decisions in stock trade in share market.

Bagher A. et al. (2017), in term of stock trading the investors and shareholders focus on the factors of social, psychological and financial behavior are studied and affect the behavior of investors and traders and taken into significant external factors in trading of stocks. The impact of external factors was measured on risk and return; attitude towards products and investment purpose were calculated with moderating role of brand information.

Shafeeq Ahmad, 2017, stated that factors, broker recommendation and preference are highly influence the investors' behavior making financial decisions and trading stock in Pakistan.

Risius M, et al. (2015), has contributed in literature that the average of negative emotionality strengthens as a important in specific movement of stock price which attached with company. The emotion and attitudes analysis define the increase in depression and happiness strength is connected with a significant decrease in company specific stock price. The attitudes and emotions analysis define the increase in depression and happiness is connected with decrease in prices of companies stock significantly. The emotion analysis particularly shows the increases of depression and happiness are related with important devalue of a company's specific stock price.

Hoffmann A.O.I. et al. (2015) described in his research that gain increases the positive emotions. While loss lead the negative emotions and this relationship is not significant in statically. The satisfaction and behavioral loyalty decreases due to experiencing negative emotions as measured by buying frequency and volume and increases the tendency of shareholders to record complaint.

According to Aspara, et al., 2015, stated that traditional finance theory refers that traders and investors select the stock to increase risk adjusted returns. Therefore; investors not only assume 
normal goal of maximum return and they also drive the background goal likewise self analyzed stocks by investors in stock trading. Using the theory of planned behavior as a tool, that individual's intention to perform behavior is guided by their general feelings indicating their favorableness or un-favorableness toward the behavior.

Khoa C. P. J.Z., et al., (2014). Define that it's a concluded that Behavioral finance and Traditional finance influence investors decision of investment. Following the Author, Shafi, (2014), define the traders and shareholders behavior analyzed in four categories which includes economical, social, demographical and last one is psychological.

Rakesh, (2014), find out that speculator fallacy and its various types in Bombay Stock Exchange market that trouble of expectations of shareholders investing in shares of company are adversely trouble the out-come of invested capital in stock.

Aspara, 2013, found that periodically study showed evidence that shareholder-investors buy stock of company they have knowledge and like it

According to Lin, (2011), that when investors begin behaving like others however taking independent decision by the available information of share and company and follow investment decision of majority shareholders and investors rather than depending on stock price list and movements that increase investors risk and return factors.

Strahilevitz, et al. (2011), define that repurchasing of stock not favor in decision making when investors was sold a stock in low price and after that going to repurchasing on high price of share on this situation investors avoid and disappointed such kind of decision. While those investors who bought share in a low price comparative in their past purchasing history and sold it for positive experience and joy high price that share in stock market and this increase positive emotions satisfaction, and behavior loyalty in trading of stock.

Nofsinger, et al. (2008), stated that emotion lead people to separate from the investment decision making process of logical reasoning from logical reasoning. Specifically shareholders incline to lose victim misattribution bias and wrong attributes investor's current mood to the financial decision and face sentiment affects the cost of capital.

Rita Martenson, (2008), have described that customer contact persons have increase behavioral and attitude loyalty and the impact is more for more complicates than for low complicates. Further author define that the role of contactors differs for different investors groups. Contact person bring a understanding able influence on investors' decisions as well as on their behavioral and attitudinal loyalty.

Baker M. et al. (2007), it may have real consequences for the allocation of corporate investment capital between safer and more speculative firms. And Fogel, 2006, investors strive to keep away from negative experiences and feelings which are related with loss and to promote the positive experiences and feelings related to gain.

Aydin, et al. (2005), Brand trust is the positive belief felt by the consumer toward a brand, product or company, which has a risk-decreasing effect and can be positively associated with purchasing behavior. And Frieder L., et al., Institutional holdings are significantly influenced by a term that captures brand perception, though brand awareness is more important than overall brand image in determining holdings, they contribute to this literature by addressing how brand perceptions influence the incentive to hold a company's stock. 
Shefrin, (2001), added his conclusion in literature that behavioral finance analyzes the influence of human psychology on the investment decision making by shareholders and traders. Adding on this statement the experts of investment, they recognize a statement stated financial behavior believe that cognitive and psychological biases likewise overconfidence, informational biases, representative biases create financial markets expected.

\subsection{Definitions of Constructs}

2.2.1. Financial Behavior: financial behavior is defined as how good a household or individual manage financial resources that includes savings, budget, financial planning, insurance and investment (Yeti M.L. and Beby K.H., 2017). According to Joo S. and Grable J.E, that attitude and behavior of individuals in financial field is called as financial behavior.

2.2.2 Attitudinal Loyalty: the form of customer loyalty that is based on psychological process, resulting in repeatedly preferring one object (product, brand, retailer and etc) to other substitutive ones (Gonzalo Moreno W., 2017).

2.2.3 Behavioral Loyalty: the form of customer loyalty that consists in the repetition of a purchase behavior, without any mental and/or psychological considerations justifying such kind of behavior and no clear preference for the purchased object (Gonzalo Moreno W., 2017). Behavior loyalty is when a customer continues to buy or use a particular product, service or brand (Encyclopedia, updated 2016)

2.2.4 Disappointment: defined as an emotional response to a bad outcome experienced as a result of state of the world (Summers and Duxbury, 2012).

2.2.5 Investor Satisfaction: describes as the effects of emotions from stock return experiences on the long term engagement with company (Hoffmann A.O.I, 2015). Investor satisfaction is defined as a degree of similarity investments result that its expectations (Aleksandra Rutkowska, 2015).

2.2.6 Financial Knowledge: financial awareness and understanding about financial concepts and procedures as well as the use of this understanding to solve financial problems (Adriana B.V., 2017).

2.2.7 Familarity: a good knowledge of something or the fact that individual knows it so well.

2.2.8 Regret: a feeling of sadness about something wrong or about a mistake that individual have made and wish it could have been different and better.

\section{Research Framework}

The research framework has been adopted from Hoffmann A.O.I, (2015). The conceptual model proposes that selling and purchasing of share leads the shareholder's experience positive (negative) financial behavior. In this research proposal it is assumed that the shareholder to be trader and brokers of the respective companies either investors in Karachi and Karachi Stock Exchange.

Inspired by Hoffmann A.O.I, (2015); research, firstly focuses on the shareholder customer's attitudinal and behavioral loyalty; investment satisfaction and preference, tendency to relate in positive financial behavior, and the likelihood of filing complaints. In particular, when an investor selling stocks for gain and positively affected becomes in engaging behavior loyalty and 
satisfaction; and when selling of stocks in loss; the investors thinking about switching and making complain which are negatively affected investors behavior. Preference intentions are increases when selling of stock for gain and strengthen satisfaction and loyalty to the company and positively affected investors. Investors liking to file complaints when selling of a stock in loss and affected negatively.

In the Figure below the independent variable is experience and on other hand positive (negative) financial behavior are dependent variables and also factors are given in the figure. The measurement is examined through these factors and hypothesis are examined the attitude and financial behavior of investor's attitude \& behavior loyalty and investor satisfaction which related stock trade of a company. Research framework has adopted from Hoffman A.O.I (2015).

We have did use the designed questionnaire and questionnaire design was adopted from the study of Hoffman A.O.I (2015). Following researcher's design the data was collected with adopted questionnaire.

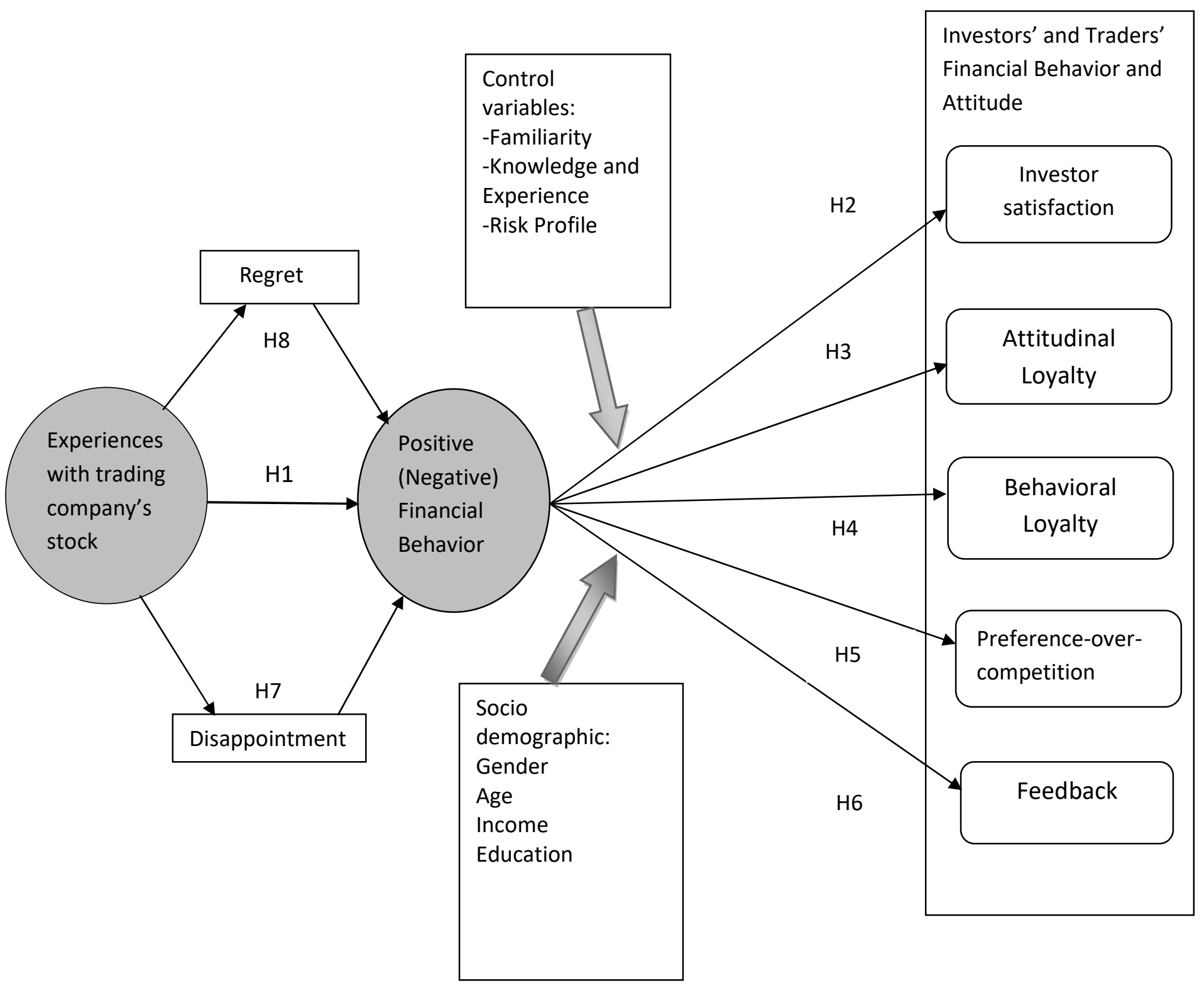




\subsection{Hypothesis}

H1-Favorable experiences trading with companies stock, such as selling of stock for a gain increases positive financial behavior of being excited, enthusiastic and determined (stress, sadness for negative).

H2-Investor's positive financial behavior cause an increase in investor satisfaction with company

H3-Investor's positive financial behavior cause an increase in attitudinal loyalty with company

H4-Investor's positive financial behavior cause an increase in behavioral loyalty with company

H5-Investor's positive financial behavior increases of investor like-hood of preferring shares from company individuals owned stock compared to shares from competitors

H6-Investor's positive financial behavior increases their tendency to file feedback or complain against company

H7-Disappointment does not mediate the relationship between gain and loss; stock performance of company and positive financial behavior

H8-Regret does not mediate relationship between making gain and loss; stock performance of company and positive financial behavior

\subsection{Sample and Sampling Design}

The sample size has defined from few scholars with using Partial Least Square structural equation model (PLA-SEM). Here as PLS-SEM is more efficient in small population of respondents (Fornell and Bookstein, 1982; Willaby et al. 2015). Further PLS-SEM is best in providing satisfactory findings where small sample with contains of some constructs in model (Willaby et al. 2015). By calculating relationship of structural and measurement model by applying PLS-SEM (Reinartz et al., 2009; Henseler et al., 2014). In PLS-SEM; sample size for structural and measurement model measured by power tables (Hair et al. 2017b). The snowball technique refers as a cost efficient technique, whereas snowball technique allows an existing respondent to arrange future respondents; this technique defined as a chain or referral technique (Hair et al. 2018).

\section{Selection of PLS-SEM}

Working in partial least square-structural equation model is effective for analyzing data collection especially with small sample size. Based on the scholars findings and using that PLSSEM is providing reliable and valid measurements while putting secondary or primary data when finding the relationship of measurement and structural model (Hair et al. 2018).

After 2010 PLS-SEM is more observed in many published journals basically in social sciences and many disciplines likewise international management (Richter et al. 2015). The using of PLSSEM approach has significantly increased towards CB-SEM when analyzing small sample size data (Hair et al. 2017b). Adding more PLS-SEM approach is effectively recommended for 
variances based to determine the characteristics (Hair et al. 2017b). according to Rigdon et al. (2017), who suggested that PLS-SEM is different and ease for small data analysis and now days most of the researchers who approaching PLS-SEM by variance-based (Rigdon et al. 2017). In this study, measuring investors and traders' positive financial behavior and assessing experiences with companies' stock performance by using partial least square path method and variance based structural equation modeling to get results of research. Although mean, median, standard deviation, $\mathrm{T}$-statics and $\mathrm{R}^{2} \& f^{2}$ values and $\mathrm{P}$ values are most important and common functions for this study. Data has been analyzed with SmartPLS \&PLS-SEM.

\section{Results and Data Analysis}

The calculation of Research framework, it is the first examination of investor's positive financial behavior which worked as deliberated. However we calculated effect trading stock for a gain on positive financial behavior and share-owner investors' behavior and attitude, the making and concluded tests for research framework for the gain and loss manipulating. The structural equation model (SEM) and partial least square (PLS) are used for data analyzing. The research model is similarly complicated and population size is smallest and like PLS approach as smartPLS (Ringle, et al. 2005), and based on SEM method is recommended over covariance (Hair, et al. 2011). Therefore PLS-method had applied for 5000 sub-samples for process of bootstrapping and changes in sign (Hair, et al. 2011). The table 3, summary of results of hypothesis test.

Ground on the finding of Hoffmann A.O.I, (2015), the respondents are decide to recall a profit on the behalf of trading companies share were anticipated to growth in gain more positive experiences and attitudes than the respondents of the loss. The respondents are experiences to positive behaviors in trade. Independent sample t-test were carry to find the impact and effect of investors and traders on constructs of positive and negative financial behavior, regret and disappointment. Before discussing the actual results we have analyzed the socio demographic and control variable values which are given from bellow to discuss demographics and control variables.

\section{Socio Demographics}

In demographics of this research is basically concluded on shareholders and traders' age, education, income and employee status has been predicted in Smart PLS-SEM.

The frequency and cumulative percent showed in terms of gender, while total no. of respondents are 85 in which 77 are males and 7 of females. This survey questionnaire distributed among investors', traders and officials of Karachi Stock Exchange, Pakistan. The cumulative percent $($ male $=90.6 ;$ female $=98.8)$ and valid percent $($ male $=90.6$; female $=8.2)$ have shown in gender figure 1 and $90.59 \%$ are males' respondents and $8.24 \%$ of female participants in this research. In age frequencies showed and largest average of 36-45 age and their $48.24 \%$ and younger investors' under age of 26-35 and 24.71\% while backward percentage of 46-55 age's percentage is $65 \%$ and last $9.41 \%$ investors whose age greater than 56 . However showing 46 participants who have education of higher than bachelor $54.12 \%$ and $44.71 \%$ are respondents who educated bachelor degree. The largest no. of respondents whose income $>100,000$ (PRs. 100,000) and their percentage stood at $40 \%$ and least $9.41 \%$ for income of $26,000-50,000$ of respondents. Although in which $37.65 \%$ respondents are working in private sector job and $29.41 \%$ are brokers/traders. The least $5.88 \%$ are investors who have their own running business.

\subsection{Control Variables}


In the familiarity, where $43.53 \%$ is the largest fact of very well familiar with financial calculations and least 5.88\% respondents don't response such questionnaire. And $31.76 \%$ of respondents who extremely familiar with trading and financial calculations. The financial knowledge means financial education and awareness about company where shareholders are going to invest their capital for the purpose of gain. Hence, the most traders and brokers have expertise knowledge (43.53\%); investors' and brokers they have working knowledge (31.76\%) which means they come for purchase and sale of shares in market they don't have much shares for longer period of time; And only $23.53 \%$ of investors' have little knowledge. The investors' and traders they have extended financial experience of investment in stock market for profit they come under age of 40-55; extended experiences have percent of $47.06 \%$. And $15.29 \%$ of investors' and traders who took decision in very extended experience for stock trading while $30.59 \%$ those who are limited experiences of trading.

Investors' taking risk for the purpose of profit in trade and $47.06 \%$ is the largest figure of percent they invested their capital and take high risk in investment on the basis of their positive experiences of past, there are age average of 48 and followed by $35.29 \%$ who took decision for the moderate risk and they under the age average of 35 . The last figure of $1.18 \%$ who are under the age 30 and they newly invested in stock, their decision based on their brokers and relative suggestion to invest in stock trading so small portion of investment from younger side in market.

\section{Assessment of PLS Measurement Model}

In measurement model there several findings which relate measuring and analyzing. First is loadings and examining of loadings by using measurement model in PLS-SEM with threshold of above 0.708 for reliability (Hair et al. 2018). In second step; composite reliability for assessing composite reliability mainly scholars refers Joreskog's (1971) work. The values between 0.60 and 0.70 are consider as acceptable and values from 0.70 to 0.90 consider as satisfactory. Hence value from 0.95 plus as a problematic value which is declining composite reliability (Diamantopoulos et al. 2012). The calculation applied for measuring convergent validity is average variance extracted (AVE) for all variables (Hair et al. 2018). Valuation of AVE is 0.50 or higher which shows constructs are determined 50\% of variance of variables (Hair et al. 2018). In last, assessment of Discriminant validity where constructs statistically differ from each other by using structural model (Fornell and Larcker, 1981).

In the bellow table (Table. 01), we analyze the Cronbach Alpha value which are greater than the 0.708 of composite reliability is above threshold of 0.708 (Hair, et al. 2014). The table showed all factors are under the threshold value which means the all factors analyzing are reliable except preference over competition (Alpha value 0.823), all factors have more than 0.708 regarding Alpha value in the table. Therefore the Composite Reliability have valued over 0.708 of all factors are greater than the 0.708 they are reliable (Hair et al. 2014), the most of factors have valued 1 which larger and showed construct reliability of factors in the bellow table.

\subsection{Constructs Reliability Table}

\begin{tabular}{|l|c|c|c|c|c|}
\hline & $\begin{array}{c}\text { Cronbac } \\
\text { h's Alpha }\end{array}$ & rho_A & $\begin{array}{c}\text { Composite } \\
\text { Reliability }\end{array}$ & $\begin{array}{c}\text { Average } \\
\text { Variance } \\
\text { Extracted } \\
\text { (AVE) }\end{array}$ & VIF \\
\hline Disappointment & 0.83 & 0.86 & 0.921 & 0.853 & 2.015 \\
\hline
\end{tabular}




\begin{tabular}{|l|l|l|l|l|c|}
\hline Financial Behavior & 0.846 & 0.867 & 0.907 & 0.764 & 1 \\
\hline Investor Satisfaction & 0.766 & 0.773 & 0.865 & 0.682 & 1.764 \\
\hline $\begin{array}{c}\text { Preference } \\
\text { over_Competition }\end{array}$ & 0.577 & 0.599 & 0.823 & 0.7 & 1.196 \\
\hline Regret & 0.688 & 0.952 & 0.851 & 0.743 & 1.379 \\
\hline
\end{tabular}

Table No. 01

In this table we also measure the Average Variance Extracted value which is above the value of threshold of 0.5 are reliable. Thus the in the table we showed that all value are above the value 0.5 which means all factor of Average Variance Extracted are above threshold of 0.5 thus all constructs are reliable (Hair et al. 2014). Mostly the factors have more than threshold value in all type of value in above figure which shows the construct reliability of hypothesis due positive value of all dependent variables. Average variance extracted could meet a small value of 0.50 (Hair, et al. 2014; Limpin, 2018). Smart-PLS is used widely in social science and business research. The Smart-PLS analysis was managed by using Smart-PLS 4.0 software (Hair et al, 2013; Sarstedt, 2013). The size of this study is smaller but using the Smart-PLS reduce the limitation because of it could assist a minimum sample size (Arndt, 1967). With references of these researchers it has been stated that all values of constructs in above table are acceptable and reliable. The values of Average Variance Extracted (AVE) are greater than .5 identifying satisfactory level of validity of construct reliability (Hair, et al. 2011; Ning 2014).

\subsection{Outer Loadings Table}

\begin{tabular}{|c|c|c|c|c|c|c|c|c|c|c|c|c|c|}
\hline & $\begin{array}{c}\text { Atti } \\
\text { tudi } \\
\text { nal } \\
\text { _Lo } \\
\text { yalt } \\
\text { y } \\
\end{array}$ & $\begin{array}{c}\text { Beha } \\
\text { vior } \\
\text { al_L } \\
\text { oyalt } \\
\text { y }\end{array}$ & $\begin{array}{l}\text { Disap } \\
\text { point } \\
\text { ment }\end{array}$ & $\begin{array}{l}\text { Edu } \\
\text { cati } \\
\text { on }\end{array}$ & $\begin{array}{c}\text { Fa } \\
\text { mil } \\
\text { arit } \\
\text { y }\end{array}$ & $\begin{array}{l}\text { Feed } \\
\text { back }\end{array}$ & $\begin{array}{c}\text { Finan } \\
\text { cial } \\
\text { Beha } \\
\text { vior }\end{array}$ & $\begin{array}{c}\text { Fina } \\
\text { ncial } \\
\text { Kno } \\
\text { wled } \\
\text { ge }\end{array}$ & $\begin{array}{c}\text { Finan } \\
\text { cial_K } \\
\mathbf{n} \\
\end{array}$ & $\begin{array}{l}\text { Invest } \\
\text { or } \\
\text { Satisfa } \\
\text { ction }\end{array}$ & $\begin{array}{c}\text { Prefe } \\
\text { rnce } \\
\text { over_- } \\
\text { Comp } \\
\text { etitio } \\
\text { n } \\
\end{array}$ & $\begin{array}{c}\text { Regre } \\
t \\
\end{array}$ & $\begin{array}{r}\text { Risk } \\
\text { Pro } \\
\text { file } \\
\end{array}$ \\
\hline D1 & & & 0.941 & & & & & & & & & & \\
\hline $\mathrm{D} 2$ & & & 0.906 & & & & & & & & & & \\
\hline FBN1 & & & & & & & 0.849 & & & & & & \\
\hline FBN2 & & & & & & & 0.926 & & & & & & \\
\hline FBN3 & & & & & & & 0.845 & & & & & & \\
\hline IS1 & & & & & & & & & & 0.772 & & & \\
\hline IS2 & & & & & & & & & & 0.84 & & & \\
\hline IS3 & & & & & & & & & & 0.863 & & & \\
\hline POC1 & & & & & & & & & & & 0.878 & & \\
\hline POC2 & & & & & & & & & & & 0.793 & & \\
\hline $\mathrm{R} 2$ & & & & & & & & & & & & 0.95 & \\
\hline R3 & & & & & & & & & & & & 0.763 & \\
\hline
\end{tabular}

Table No. 02 
In this above table where value showed their results in the category of outer-loading table. The values are greater than 0.5 so thus the values are reliable of all construct factors. According to Hair, et al. (2014), stated the value should be greater than the 0.5 of findings of outer-loadings tables, it means the constructs factors reliable and acceptable. The finding confirms that all construct are $>0.5$ which become the acceptable in this table attitudinal loyalty, behavioral loyalty, education, financial behavior in negative, financial knowledge, familiarity and risk profile (1) construct are more effective in stock trading towards investor's satisfaction and investment decision. Rests of construct factor are also acceptable they have behind the above factor's value. Their value is more than 0.5 so these remaining factors considerable as well. According to Hair that lading of measurements of each factor on its correlate with construct should not be less than 0.5 . The construct variables mostly value 1 and $>0.5$ which is considerable and acceptable (Norsis, 2008).

\subsection{Discriminate Validity}

Assess of Discriminant validity by using Fornell Larcker criterion (1998). The tool used to measure differences of average variance extracted (AVE) of square root of variance extracted (AVE) with correlation latents constructs. The square root of all variable's average variance extracted (AVE) would higher value than the associations with other construct. According to Messick (1989), Discriminant validity is confirmatory that the analyze does not related each other constructs and similar, even though distinct constructs. The connection coefficients between the findings of constructs and measure of supposed different constructs.

\begin{tabular}{|c|c|c|c|c|c|c|c|c|c|c|c|c|c|}
\hline & $\begin{array}{c}\text { Attitu } \\
\text { dinal_- } \\
\text { Loyalt } \\
y\end{array}$ & $\begin{array}{l}\text { Behavi } \\
\text { oral_L } \\
\text { oyalty }\end{array}$ & $\begin{array}{l}\text { Disap } \\
\text { point } \\
\text { ment }\end{array}$ & $\begin{array}{c}\text { Educat } \\
\text { ion }\end{array}$ & $\begin{array}{c}\text { Familar } \\
\text { ity }\end{array}$ & $\begin{array}{l}\text { Feed } \\
\text { back }\end{array}$ & $\mid \begin{array}{c}\text { Financi } \\
\text { al } \\
\text { Behavi } \\
\text { or }\end{array}$ & $\begin{array}{c}\text { Financia } \\
\text { I } \\
\text { Knowle } \\
\text { dge }\end{array}$ & $\begin{array}{c}\text { Financial } \\
{ }^{\mathrm{Kn}}\end{array}$ & \begin{tabular}{|} 
Investo \\
$r$ \\
Satisfac \\
tion
\end{tabular} & $\begin{array}{c}\text { Prefere } \\
\text { nce } \\
\text { over_C } \\
\text { ompeti } \\
\text { tion }\end{array}$ & Regret & $\begin{array}{c}\text { Risk } \\
\text { Pro } \\
\text { file }\end{array}$ \\
\hline $\begin{array}{l}\text { Attitudinal_L } \\
\text { oyalty }\end{array}$ & 1 & & & & & & & & & & & & \\
\hline $\begin{array}{l}\text { Behavioral_L } \\
\text { oyalty }\end{array}$ & 0.44 & 1 & & & & & & & & & & & \\
\hline $\begin{array}{l}\text { Disappointm } \\
\text { ent }\end{array}$ & -0.238 & $|-0.342|$ & 0.924 & & & & & & & & & & \\
\hline Education & 0.14 & 0.132 & -0.225 & 1 & & & & & & & & & \\
\hline Familiarity & $-0.027 \mid$ & $|-0.008|$ & $\mid-0.28$ & 0.476 & 1 & & & & & & & & \\
\hline Feedback & 0.14 & 0.126 & -0.381 & 0.255 & 0.515 & 1 & & & & & & & \\
\hline Financial & -0.153 & -0.123 & 0.328 & -0.053 & -0.144 & - & 0.874 & & & & & & \\
\hline
\end{tabular}




\begin{tabular}{|l|c|c|c|c|c|c|c|c|c|c|c|c|c|}
\hline Behavior & & & & & & 0.324 & & & & & & & \\
\hline $\begin{array}{l}\text { Financial } \\
\text { Knowledge }\end{array}$ & -0.01 & 0.03 & -0.207 & 0.423 & 0.771 & 0.441 & -0.197 & $\mathbf{1}$ & & & & & \\
\hline Financial_Kn & 0.089 & 0.019 & -0.364 & 0.539 & 0.739 & 0.407 & -0.189 & 0.795 & $\mathbf{1}$ & & & & \\
\hline $\begin{array}{l}\text { Investor } \\
\text { Satisfaction }\end{array}$ & 0.089 & 0.259 & -0.231 & 0.398 & 0.515 & 0.579 & -0.196 & 0.467 & 0.408 & $\mathbf{0 . 8 2 6}$ & & & \\
\hline $\begin{array}{l}\text { Preference } \\
\text { over_Compe } \\
\text { tition }\end{array}$ & 0.19 & 0.383 & 0.198 & 0.044 & -0.151 & 0.045 & 0.212 & -0.164 & -0.237 & 0.118 & $\mathbf{0 . 8 3 7}$ & & \\
\hline Regret & -0.088 & -0.222 & 0.527 & -0.217 & -0.196 & -0.29 & 0.393 & -0.217 & -0.238 & -0.127 & 0.153 & $\mathbf{0 . 8 6 2}$ & \\
\hline Risk_Profile & 0.025 & -0.044 & -0.21 & 0.358 & 0.491 & 0.251 & -0.082 & 0.618 & 0.66 & 0.357 & -0.117 & -0.212 & $\mathbf{1}$ \\
\hline
\end{tabular}

In this table, we measure the Discriminant validity of all construct factors and values randomly are higher than 0.708 resulted as a reliable finding in above table of all variables in the table 03 . According to Fornell Lacker C. (1988), that values of diagonal should be $>0.708$ are reliable, in reference of this statement the findings of this research that are diagonally are greater than value of 0.708 . In this table (Table No. 03) all construct hypothesis values at diagonal are $>0.708$. Discriminant validity are given in each constructs' AVE is greater than squared correlation with any factor of construct (Fornell and Larcker, 1981) and each factor loads higher on the constructs are supposed to measure (Chin, 1998). Thus the table.03 results established that all construct meets the criteria of Discriminant validity regarding the value of 0.708 (Fornell L. C, 1988).

Following identify the findings and measurement model, the reliability and validity of results are assessed in the table. 03 . We measure Discriminant validity of formative construct by identifying the variables loading and average variance extracted (AVE). Subsequently all variables load significantly $(>0.70)$ on their individually fundamental constructs (Hulland, 1998).

\section{Assessment of Structural Model}

After the measurement of construct model as a reliable and valid then need to assess second step of the data analyzing. The assessment of structural model based on PLS-SEM whereas assessing the determination $\left(R^{2}\right)$, significance of path coefficient, predictive relevance $\left(\mathrm{Q}^{2}\right)$ and effect of $f^{2}$ by using PLS-SEM process (Shmueli et al. 2016). However value of VIF above 5 shows probable collinearity issues between predictive constructs where as problems would be effective in lower valuation from 5 for VIF (Mason and Perreault, 1991; Becker et al. 2015). The $\mathrm{f}^{2}$ effect helps in defining dependent variable with comparing path coefficient (Nitzl et al. 2016). According to criterion acceptable values of $0.02,0.15$ and 0.35 considering as small, medium and large effect size (Cohen, 1988). 
The analyzing involves examining the model's relationships with constructs and predictive capabilities of constructs. We have examined the structural model for collinearity. On this reason that estimation of path coefficient in structural model is basically on PLS regression of each endogenous latent variable on its corresponding constructs. The major criteria for assessing the structural model in PLS-SEM are four steps which here given as: Step1- the significance of path coefficients, step2- the level of $\mathrm{R}^{2}$ values and step3- the $\mathrm{f}^{2}$ effective size and step4- the predictive relevance of $\mathrm{Q}^{2}$.

\subsection{Assessment of Collinearity issues Model (VIF)}

No collinearity among latent variables was found as a variance inflation factor (VIF) for all latent variables is smaller than threshold value of 5, Hair et al. (2011).

\begin{tabular}{|l|c|}
\hline & VIF \\
\hline Disappointment 1 & $\mathbf{2 . 0 1 5}$ \\
\hline Disappointment 2 & $\mathbf{2 . 0 1 5}$ \\
\hline Financial Behavior Negative 1 & $\mathbf{1 . 7 8 5}$ \\
\hline Financial Behavior Negative 2 & $\mathbf{2 . 8 7 5}$ \\
\hline Financial Behavior Negative 3 & $\mathbf{2 . 2 7 3}$ \\
\hline Investor Satisfaction 1 & $\mathbf{1 . 4 1 4}$ \\
\hline Investor Satisfaction 2 & $\mathbf{1 . 6 4 5}$ \\
\hline Investor Satisfaction 3 & $\mathbf{1 . 7 6 4}$ \\
\hline Preference Over Competition 1 & $\mathbf{1 . 1 9 6}$ \\
\hline Preference Over Competition 2 & $\mathbf{1 . 1 9 6}$ \\
\hline Regret 2 & $\mathbf{1 . 3 7 9}$ \\
\hline Regret 3 & $\mathbf{1 . 3 7 9}$ \\
\hline
\end{tabular}

Table No. 04

Collinearity constructs has no issue for the constructs of variance inflation factors (VIF) is smaller than the five, Hair et al. (2011). This means the finding of this collinearity constructs are reliable and valid. The most of factor that is the financial behavior negative $(\mathrm{VIF}=2.785)$ larger than the other factors of variance inflation factor in the above table and rest of construct are also valid and reliable because of collinearity construct's have low value and under five so these all constructs are valid and acceptable. All negative financial behavior is weak in this table and their values under the five and it has no issue with experiences of investors and traders in stock.

\subsection{Assessment of Model for Path Coefficient}

\begin{tabular}{|l|c|c|c|c|c|c|}
\hline & $\begin{array}{l}\text { Original } \\
\text { Sample } \\
(\mathbf{O})\end{array}$ & $\begin{array}{l}\text { Sample } \\
\text { Mean } \\
(\mathbf{M})\end{array}$ & $\begin{array}{l}\text { Standard } \\
\text { Deviation } \\
\text { (STDEV) }\end{array}$ & $\begin{array}{l}\text { T Statistics } \\
(\mid \mathbf{O} / \text { STDEV|) }\end{array}$ & P Values & Result \\
\hline $\begin{array}{l}\text { Disappointment -> } \\
\text { Financial Behavior }\end{array}$ & 0.167 & 0.175 & 0.112 & 1.498 & 0.134 & NS \\
\hline $\begin{array}{l}\text { Education -> } \\
\text { Attitudinal_Loyalty }\end{array}$ & 0.139 & 0.137 & 0.125 & 1.111 & 0.267 & NS \\
\hline $\begin{array}{l}\text { Education -> } \\
\text { Behavioral_Loyalty }\end{array}$ & 0.196 & 0.196 & 0.121 & 1.626 & 0.104 & NS \\
\hline Education -> Feedback & 0.069 & 0.046 & 0.137 & 0.506 & 0.613 & NS \\
\hline Education -> Investor & 0.221 & 0.211 & 0.115 & 1.917 & 0.055 & S \\
\hline
\end{tabular}




\begin{tabular}{|l|c|c|c|c|c|c|}
\hline Satisfaction & & & & & & \\
\hline $\begin{array}{l}\text { Education -> Preference } \\
\text { over_Competition }\end{array}$ & 0.233 & 0.228 & 0.137 & 1.696 & 0.04 & S \\
\hline $\begin{array}{l}\text { Familiarity -> } \\
\text { Behavioral_Loyalty }\end{array}$ & -0.132 & -0.123 & 0.163 & 0.805 & 0.421 & NS \\
\hline $\begin{array}{l}\text { Familiarity -> Investor } \\
\text { Satisfaction }\end{array}$ & 0.37 & 0.365 & 0.166 & 2.222 & 0.026 & S \\
\hline $\begin{array}{l}\text { Familiarity -> Preference } \\
\text { over_Competition }\end{array}$ & -0.021 & -0.022 & 0.181 & 0.114 & 0.909 & NS \\
\hline $\begin{array}{l}\text { Financial Behavior -> } \\
\text { Attitudinal_Loyalty }\end{array}$ & -0.159 & -0.16 & 0.105 & 1.511 & 0.131 & NS \\
\hline $\begin{array}{l}\text { Financial Behavior -> } \\
\text { Behavioral_Loyalty }\end{array}$ & -0.123 & -0.119 & 0.132 & 0.938 & 0.348 & NS \\
\hline $\begin{array}{l}\text { Financial Behavior -> } \\
\text { Feedback }\end{array}$ & -0.242 & -0.236 & 0.083 & 2.913 & 0.004 & S \\
\hline $\begin{array}{l}\text { Financial Behavior -> } \\
\text { Investor Satisfaction }\end{array}$ & -0.131 & -0.13 & 0.101 & 1.307 & 0.191 & NS \\
\hline
\end{tabular}

Table No. 05

In the above table sample mean values are showed that six variables are accepted means the value have under the acceptable where three types of calculation as per Wetzels et al. (2009, Gof $=0.1$ is smaller value which means weak value, Gof $=0.25$ is medium and moderate value and last is Gof $=0.36$ is larger and which means strong value of model fit. In this table the disappointment towards financial behavior $(\mathrm{M}=0.17, \mathrm{SD}=0.112$; $\mathrm{T}$-statistics $=1.498, \mathrm{p}=$ 0.134 ) has weak relationship with financial behavior, education has weak relationship with attitudinal loyalty $(\mathrm{M}=0.137, \mathrm{SD}=0.125$; T-statistics $=1.111, \mathrm{p}=0.267)$ which is nonsignificant. Education towards behavioral loyalty $(\mathrm{M}=0.196, \mathrm{SD}=0.121$; T-statistics $=1.626, \mathrm{p}$ $=0.104)$ which has weak and non-significant relationship with behavioral loyalty. And also education has no significant relationship with feedback. While education has a strong relationship $(\mathrm{M}=0.211, \mathrm{SD}=0.115$; $\mathrm{T}$-statistics $=1.917, \mathrm{p}=0.055)$ with investors satisfaction and significant. And education has a strong relation with preference over competition and significant as per effect size $(\mathrm{M}=0.228, \mathrm{SD}=0.137$; $\mathrm{T}$-statistics $=1.696, \mathrm{p}=0.04)$. Familiarity has significant and strong relationship with investor satisfaction $(\mathrm{M}=0.365, \mathrm{SD}=0.166$; $\mathrm{T}$ statistics $=2.222, \mathrm{p}=0.026)$. But familiarity has no relationship and no significant with behavioral loyalty $(\mathrm{M}=-0.123, \mathrm{SD}=0.163$; T-statistics $=0.805, \mathrm{p}=0.421)$. The financial behavior has a strong relationship and significant with feedback $(\mathrm{M}=-0.236, \mathrm{SD}=0.083$; $\mathrm{T}$ statistics $=2.913, \mathrm{p}=0.004)$. According to Cohen, (1988), $0.01=$ weak or smaller, $0.15=$ medium or moderate and $0.35=$ larger or strong also Wetzels et al (2009) is given in above statement. As per above table there has been showing the relationship of variables and no significant relationships between them.

\subsection{Assessment of $\mathbf{R}^{2}$ Value}

In this figure we have found out the $\mathrm{R}^{2}$ value of hypothesis and their constructs. The PLS approach as in smart PLS does not give statistic of all model fit (Chin, 1998). The model have evaluate by calculating the variables of $\mathrm{R}^{2}$ - values which shows the explanation of predictive factors on the respective constructs(Figure 3). Hence we work on a diagnostic tool, the Goodness of Fit (GoF) index by Tenenhaus et al. (2005). The figure 3 shows that selling of share for a loss 
explains $\left(\mathrm{R}^{2}=0.175\right)$ is medium which means the financial behavior in negative affect the shareholders' and investors financial behavior in term of getting loss.

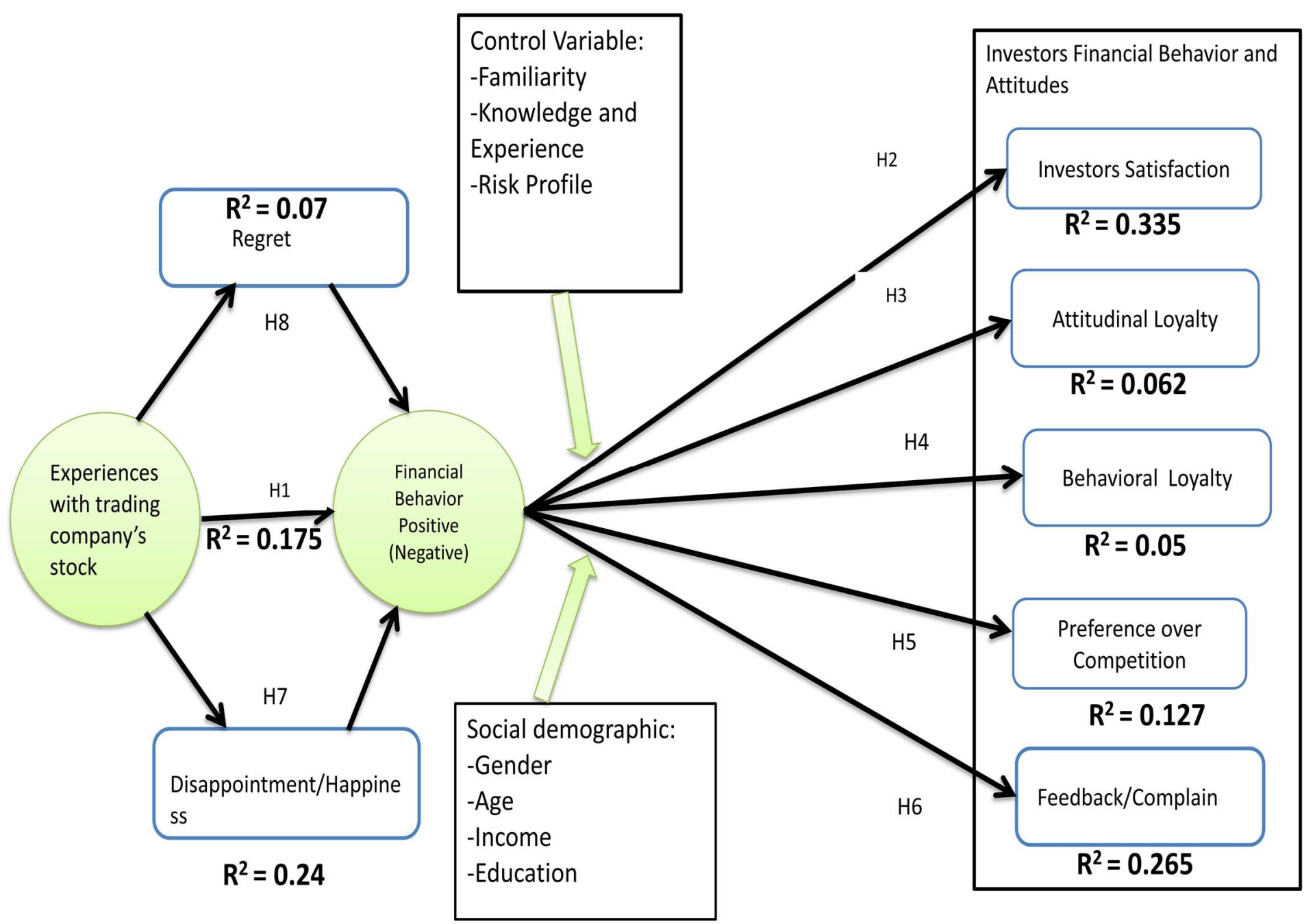

Figure No. 1

According to measurement of $\mathrm{R}^{2}$ values are divided in three categories which are smaller, medium and larger. According to Tenenhaus et al. (2005), the Gof $=0.1$ is smaller, Gof $=0.15$ is medium and larger is Gof $=0.36$. According to Henseler et al. (2009) and Hair et al. (2014), they recommended establish values herein $10 \%$ has a low variation effect; $50 \%$ as medium variation effect and $60 \%$ has strong variation effect in social sciences specifically. So the values of five construct in $\mathrm{R}^{2}$ value are moderate variation effect size. Herein in above table experience has moderate variation on positive financial behavior; and experience brings $24 \%$ variation effect. Whereas financial behavior brings moderate (33.5\%) variation in investor satisfaction. For feedback/complain $26.5 \%$ variation effect and preference over competitor has $12.7 \%$ variation effect. The investors' satisfaction has strongly variances level in the experiences of investors in terms of trading stock.

\section{$8.4 \quad f^{2}$ Effect Size}


The $f^{2}$ effect size is measurement of a particular predictive construct on endogenous constructs. In accession to evaluate the size of $\mathrm{R}^{2}$ value of endogenous constructs, the $f^{2}$ effect size could be calculated. The $f^{2}$ effect size measures the change in values of $\mathrm{R}^{2}$ when a particular exogenous construct is omitted from the model. It has used to evaluate however the omitted forecast construct has a substantive impact on the value of $\mathrm{R}^{2}$ of endogenous constructs.

The GoF measurement to calculate the global model fit is calculated as in Tenenhaus et al. (2005), $\mathrm{GoF}=\left(\mathrm{R}^{2} \times \text { Communality }\right)^{1 / 2}$. It calculates the average of $\mathrm{R}^{2}$ of the endogenous variables and the average of communality of geometric mean. The gain model with main effects only has a GoF of 0.21 which shows that a smaller global model fit as per cut off values are proposed by Wetzels et al. (2009) are $\mathrm{GoF}=0.1$ is smaller, $\mathrm{GoF}=0.25$ is medium size and $\mathrm{GoF}=.036$ is larger.

There are two author's guidelines for assessing the valid and reliable values of all constructs in this effect size and their calculation methods. The guidelines of Cohen, et al. (1988) for assessing $f^{2}$ values for the exogenous latent constructs in forecasting the endogenous constructs are effect size $=0.02$ is smaller, effect size $=0.15$ is medium and effect size $=0.35$ is larger. Although, effect sizes $\left(f^{2}\right)$ are computed as suggested by Chin and Henseler (2010) to calculated the impact of a particular predictor construct on endogenous construct are $f^{2}=\mathrm{R}^{2}$ included $-\mathrm{R}^{2}$ excluded $/ 1-\mathrm{R}^{2}$.

\begin{tabular}{|l|c|c|c|c|c|c|c|c|c|c|c|c|c|}
\hline & $\begin{array}{c}\text { Attit } \\
\text { udina } \\
\text { I_Loy } \\
\text { alty }\end{array}$ & $\begin{array}{c}\text { Beha } \\
\text { viora } \\
\text { I_Loy } \\
\text { alty }\end{array}$ & $\begin{array}{c}\text { Dis } \\
\text { app } \\
\text { oint } \\
\text { men } \\
\mathbf{t}\end{array}$ & $\begin{array}{c}\text { Edu } \\
\text { catio } \\
\mathbf{n}\end{array}$ & $\begin{array}{c}\text { Fa } \\
\text { mil } \\
\text { arit } \\
\mathbf{y}\end{array}$ & $\begin{array}{c}\text { Feed } \\
\text { back }\end{array}$ & $\begin{array}{c}\text { Fina } \\
\text { ncial } \\
\text { Beha } \\
\text { vior }\end{array}$ & $\begin{array}{c}\text { Fina } \\
\text { ncial } \\
\text { Kno } \\
\text { wled } \\
\text { ge }\end{array}$ & $\begin{array}{c}\text { Fina } \\
\text { ncial } \\
\text { Kn }\end{array}$ & $\begin{array}{c}\text { Inves } \\
\text { tor } \\
\text { Satisf } \\
\text { actio } \\
\text { n }\end{array}$ & $\begin{array}{c}\text { Prefe } \\
\text { rence } \\
\text { over } \\
\text { Co } \\
\text { mpet } \\
\text { ition }\end{array}$ & $\begin{array}{c}\text { Reg } \\
\text { ret }\end{array}$ & $\begin{array}{c}\text { Ris } \\
\text { k_P } \\
\text { rofi } \\
\text { le }\end{array}$ \\
\hline $\begin{array}{l}\text { Disappoint } \\
\text { ment }\end{array}$ & & & & & & & 0.025 & & & & & & \\
\hline Education & 0.015 & 0.028 & & & & 0.005 & & & & 0.051 & 0.043 & & \\
\hline Familarity & & 0.006 & & & & & & & & 0.072 & 0 & & \\
\hline Feedback & & & & & & & & & & & & & \\
\hline $\begin{array}{l}\text { Financial } \\
\text { Behavior }\end{array}$ & 0.026 & 0.015 & & & & 0.075 & & & & & & & \\
\hline $\begin{array}{l}\text { Financial } \\
\text { Knowledge }\end{array}$ & 0.021 & 0.004 & & & & 0.044 & & & & 0.025 & 0.029 & & \\
\hline $\begin{array}{l}\text { Financial_ } \\
\text { Kn }\end{array}$ & 0.01 & 0 & & & & 0.006 & & & & 0.019 & 0.051 & & \\
\hline Regret & & & & & & & 0.081 & & & & & & \\
\hline $\begin{array}{l}\text { Risk_Profil } \\
\text { e }\end{array}$ & 0 & 0.007 & & & & & & & & & & & \\
\hline
\end{tabular}

Table No. 07

In this table 07 , the four constructs have no effect size computed which are attitudinal and behavioral loyalty towards any other constructs in effect sizes. On other hand investors satisfaction and preference over competition are also no effects calculated. The disappointment has small value $\left(f^{2}=0.025\right)$ towards financial behavior and its impact financial behavior of investors. Education has impact on attitudinal and behavioral loyalty, feedback, investors' satisfaction and preference and its smaller impact $\left(f^{2}=0.015,0.028,0.005,0.051\right.$ and 0.043$)$. In last risk profile has small impacts with four constructs which same as for education $\left(\mathrm{f}^{2}=0.007\right.$, 
$0.003,0.015$ and $\left.f^{2}=0.001\right)$. According to both above tables all construct of endogenous have valid and reliable and in table 07 , all constructs values under smaller size of effect.

\subsection{Correlation Coefficient of Latent Variables}

In the terms of latent correlation coefficients of endogenous and exogenous constructs found out the relations of all constructs which showing in table 8, given in bellow.

\begin{tabular}{|c|c|c|c|c|c|c|c|c|c|c|c|c|c|}
\hline & $\begin{array}{c}\text { Attit } \\
\text { udin } \\
\text { al_L } \\
\text { oyalt } \\
\mathbf{y}\end{array}$ & $\begin{array}{l}\text { Beha } \\
\text { viora } \\
\text { l_Lo } \\
\text { yalty }\end{array}$ & $\begin{array}{c}\text { Disa } \\
\text { ppoi } \\
\text { ntme } \\
\text { nt }\end{array}$ & $\begin{array}{c}\text { Edu } \\
\text { cati } \\
\text { on }\end{array}$ & $\begin{array}{c}\text { Fami } \\
\text { larit } \\
y\end{array}$ & $\begin{array}{l}\text { Feed } \\
\text { back }\end{array}$ & $\begin{array}{c}\text { Fina } \\
\text { ncial } \\
\text { Beha } \\
\text { vior }\end{array}$ & $\begin{array}{c}\text { Finan } \\
\text { cial } \\
\text { Know } \\
\text { ledge }\end{array}$ & $\begin{array}{c}\text { Finan } \\
\text { cial_- } \\
\text { Kn }\end{array}$ & $\begin{array}{c}\text { Invest } \\
\text { or } \\
\text { Satisf } \\
\text { action }\end{array}$ & $\begin{array}{c}\text { Prefe } \\
\text { renc } \\
\text { e } \\
\text { over } \\
\text { Co } \\
\text { mpet } \\
\text { ition } \\
\end{array}$ & $\begin{array}{c}\text { Regr } \\
\text { et }\end{array}$ & $\begin{array}{c}\text { Risk } \\
\text { Pro } \\
\text { file }\end{array}$ \\
\hline $\begin{array}{l}\text { Attitudinal } \\
\text { _Loyalty }\end{array}$ & 1 & & & & & & & & & & & & \\
\hline $\begin{array}{l}\text { Behavioral } \\
\text { _Loyalty }\end{array}$ & 0.44 & 1 & & & & & & & & & & & \\
\hline $\begin{array}{l}\text { Disappoint } \\
\text { ment }\end{array}$ & $\begin{array}{c}- \\
0.238\end{array}$ & $\begin{array}{c}- \\
0.342\end{array}$ & 1 & & & & & & & & & & \\
\hline Education & 0.14 & 0.132 & $\begin{array}{c}- \\
0.225\end{array}$ & 1 & & & & & & & & & \\
\hline Familarity & $\begin{array}{c}- \\
0.027\end{array}$ & $\begin{array}{c}- \\
0.008\end{array}$ & -0.28 & $\begin{array}{c}0.47 \\
6\end{array}$ & 1 & & & & & & & & \\
\hline Feedback & 0.14 & 0.126 & $\begin{array}{c}- \\
0.381\end{array}$ & $\begin{array}{c}0.25 \\
5\end{array}$ & 0.515 & 1 & & & & & & & \\
\hline $\begin{array}{l}\text { Financial } \\
\text { Behavior }\end{array}$ & $\begin{array}{c}- \\
0.153\end{array}$ & $\begin{array}{c}- \\
0.123\end{array}$ & 0.328 & $\begin{array}{c}- \\
0.05 \\
3\end{array}$ & $\begin{array}{c}- \\
0.144\end{array}$ & $\begin{array}{c}- \\
0.324\end{array}$ & 1 & & & & & & \\
\hline $\begin{array}{l}\text { Financial } \\
\text { Knowledge }\end{array}$ & -0.01 & 0.03 & $\begin{array}{c}- \\
0.207\end{array}$ & $\begin{array}{c}0.42 \\
3\end{array}$ & 0.771 & 0.441 & $\begin{array}{c}- \\
0.197\end{array}$ & 1 & & & & & \\
\hline $\begin{array}{l}\text { Financial_ } \\
\text { Kn }\end{array}$ & 0.089 & 0.019 & $\begin{array}{c}- \\
0.364\end{array}$ & $\begin{array}{c}0.53 \\
9\end{array}$ & 0.739 & 0.407 & $\begin{array}{c}- \\
0.189\end{array}$ & 0.795 & 1 & & & & \\
\hline $\begin{array}{l}\text { Investor } \\
\text { Satisfaction }\end{array}$ & 0.089 & 0.259 & $\begin{array}{c}- \\
0.231\end{array}$ & $\begin{array}{c}0.39 \\
8\end{array}$ & 0.515 & 0.579 & 0.196 & 0.467 & 0.408 & 1 & & & \\
\hline $\begin{array}{l}\text { Preference } \\
\text { over_Comp } \\
\text { etition }\end{array}$ & 0.19 & 0.383 & 0.198 & $\begin{array}{c}0.04 \\
4\end{array}$ & $\begin{array}{c}- \\
0.151\end{array}$ & $\begin{array}{c}- \\
0.045\end{array}$ & 0.212 & -0.164 & -0.237 & 0.118 & 1 & & \\
\hline
\end{tabular}




\begin{tabular}{|c|c|c|c|c|c|c|c|c|c|c|c|c|c|}
\hline Regret & $\begin{array}{l}- \\
0.088\end{array}$ & $\begin{array}{l}- \\
0.222\end{array}$ & 0.527 & $\begin{array}{l}- \\
0.21 \\
7\end{array}$ & $\begin{array}{l}- \\
0.196\end{array}$ & -0.29 & 0.393 & -0.217 & -0.238 & -0.127 & 0.153 & 1 & \\
\hline $\begin{array}{l}\text { Risk_Profi } \\
\text { le }\end{array}$ & 0.025 & $\begin{array}{c}- \\
0.044\end{array}$ & -0.21 & $\begin{array}{c}0.35 \\
8\end{array}$ & 0.491 & 0.251 & $0 . \overline{082}$ & 0.618 & 0.66 & 0.357 & $0 . \overline{117}$ & $0 . \overline{212}$ & 1 \\
\hline
\end{tabular}

Table No. 08

As we discussed in previous two tables where we find the values of endogenous constructs and exogenous construct where $\mathrm{R}^{2}$ values and $f^{2}$ values are valid so this table 8 , are related with these tables. The main thing in this table 8, we have value over the zero (1) in randomly of all endogenous construct and exogenous constructs are true and valid. We evaluate the impact of socio-demographic variables and control variables as possible mediators on the relationship between gain magnitude and positive financial behavior, and the on the relationship of positive financial behavior and shareholder or investor behavior. The constructs are tested in SmartPLS (Ringle et, Al. 2005). According to researcher who investigate that values of variables are greater than zero (1) which means the finding is valid while in this tables we have findings regarding (Ringle et, al. 2005) are greater than zero in randomly thus the all constructs are established and strong relationship between endogenous and exogenous construct. Two values was observed 0 and 1 in randomly (Heinen et al. 1996) here in table 8 we have analyzed correlation coefficient of latient variables are established.

\subsection{Hypothesis Testing}

The testing of hypothesis in SmartPLS and PLS-SEM technique has been used to find out bootstrapping results of hypothesis. The following table shows that status of hypothesis in this research and their validity and relationship in investors' financial behavior in trade.

\begin{tabular}{|l|c|c|c|c|c|c|}
\hline & $\begin{array}{c}\text { Original } \\
\text { Sample } \\
(\mathrm{O})\end{array}$ & $\begin{array}{c}\text { Sample } \\
\text { Mean } \\
(\mathrm{M})\end{array}$ & $\begin{array}{c}\text { Standard } \\
\text { Deviation } \\
\text { (STDEV) }\end{array}$ & $\begin{array}{c}\text { T Statistics } \\
(|\mathrm{O} / \mathrm{STDEV}|)\end{array}$ & $\begin{array}{c}\text { P } \\
\text { Values }\end{array}$ & Status \\
\hline $\begin{array}{l}\text { Disappointment -> } \\
\text { Financial } \\
\text { Behavior_Negative }\end{array}$ & 0.233 & 0.248 & 0.117 & 1.989 & 0.047 & Accepted \\
\hline $\begin{array}{l}\text { Disappointment -> } \\
\text { Positive_Financial } \\
\text { Behavior }\end{array}$ & 0.051 & 0.05 & 0.124 & 0.409 & 0.682 & Rejected \\
\hline $\begin{array}{l}\text { Financial } \\
\text { Behavior_Negative -> } \\
\text { Attitudinal_Loyalty }\end{array}$ & 0.156 & 0.153 & 0.135 & 1.156 & 0.248 & Rejected \\
\hline $\begin{array}{l}\text { Financial } \\
\text { Behavior_Negative -> } \\
\text { Behavioral loyalty }\end{array}$ & 0.057 & 0.066 & 0.142 & 0.4 & 0.689 & Rejected \\
\hline $\begin{array}{l}\text { Financial } \\
\text { Behavior_Negative -> } \\
\text { Positive_Financial } \\
\text { Behavior }\end{array}$ & 0.355 & 0.358 & 0.12 & 2.951 & 0.003 & Accepted \\
\hline $\begin{array}{l}\text { Financial } \\
\text { Behavior_Negative -> }\end{array}$ & 0.074 & 0.083 & 0.154 & 0.484 & 0.628 & Rejected \\
\hline
\end{tabular}




\begin{tabular}{|l|c|c|c|c|c|l|}
\hline Preference_on_Competition & & & & & & \\
\hline $\begin{array}{l}\text { Financial_Eariof_Negative -> } \\
\text { Behavior_ } \\
\text { Satisfaction }\end{array}$ & -0.205 & -0.192 & 0.114 & 1.8 & 0.042 & Accepted \\
\hline $\begin{array}{l}\text { Positive_Financial } \\
\text { Behavior-> } \\
\text { Attitudinal_Loyalty }\end{array}$ & 0.316 & 0.323 & 0.107 & 2.947 & 0.003 & Accepted \\
\hline $\begin{array}{l}\text { Positive_Financial } \\
\text { Behavior -> Behavioral } \\
\text { loyalty }\end{array}$ & 0.295 & 0.308 & 0.111 & 2.656 & 0.008 & Accepted \\
\hline $\begin{array}{l}\text { Positive_Financial } \\
\text { Behavior-> } \\
\text { Preference_on_Competition }\end{array}$ & 0.149 & 0.15 & 0.145 & 1.026 & 0.305 & Rejected \\
\hline $\begin{array}{l}\text { Positive_Financial } \\
\text { Behavior-> Satisfaction }\end{array}$ & 0.517 & 0.524 & 0.086 & 6.004 & 0 & Accepted \\
\hline
\end{tabular}

Table No. 10

In table. 10 there are showing the results of hypothesis that six hypotheses are accepted and five rejected respectively. In this table 10, in which rejected means no significant relationship between two hypothesis and accepted means they have significant relationships and values computed in SmartPLS as per Wetzels et al (2009) and Cohen et al (1988) which are 0.1 is smaller, 0.15 is medium and 0.36 is larger; on the basis these researchers this findings are valid and acceptable. Disappointment has no significant relationship $(M=0.248 ; p=0.047)$ with negative financial behavior; the negative financial behavior has no significant relationship with positive financial behavior $(M=0.358$; $p=0.003)$. No significant relationship between negative financial behavior and investor satisfaction $(M=-0.192 ; p=0.042)$. Positive financial behavior has no significant relationship with two hypotheses which are attitudinal loyalty $(M=0.323 ; p=$ $0.003)$ and behavioral loyalty $(M=0.308 ; p=0.008)$. Positive financial behavior has no significant relationship with satisfaction $(M=0.524 ; p=0.00)$. Disappointment has a significant relation with positive financial behavior $(M=0.05 ; p=0.682)$; negative financial behavior has significant relationships with attitudinal loyalty $(M=0.153 ; p=0.248)$ and behavioral loyalty $(M$ $=0.066 ; p=0.689)$. And negative financial behavior also has a significant relation with preference over competition $(M=0.083 ; p=0.628)$. Last hypothesis which is positive financial behavior has a significant relationship with preference over competition $(\mathrm{M}=0.15 ; p=0.305)$. These findings showed that their relationships and importance for each other and effective for investors' behavior in decision making in stock trade.

\section{Conclusion}

Therefore the conclusion is based on results and findings of this study, acknowledging about findings and now term is to discuss and conclusion of results. To the best knowledge this research study is originality that this is first to find link between positive experiences with stock trading of companies, the resulting financial behavior and investors satisfaction and their effect on investors attitude and behavioral loyalty. As per findings, the results make a few extensions to previous study on shareholders based customer regarding negative experiences increases dissatisfaction and switching of company's products of stocks over products from the competitors and engage in negative feelings (Hoffmann et al. 2015; Heskett's et al. 2002).

The findings contribute to the study's literature, which put forward that gain making longer and positive experiences than losses. Specifically, finding that gain lead to positive experiences; 
attitudes and financial behavior, which is mediating between investors satisfaction and positive experiences. While losses increases the disappointment and sadness feelings and this relationship and does not significantly through statically. Experiencing positive financial behavior increases satisfaction, attitudinal and behavioral loyalty as measured by purchase frequency and volume based on experiences, and increases the tendency of shareholders and brokers to preference over competition and to suggest other in investment decision.

The results show that disappointment and regret has no relationship with positive financial behavior of investors' and traders. The positive experiences increases satisfaction loyalty and attitudinal loyalty and investors would feel positive due to getting positive experiences from selling of stocks; investors would appreciate themselves for having made a profitable decision. Further, this study shows that knowledge and familiarity with company and its stock strengthens the positive effect of experiences on financial behavior loyalty. According to researchers that investors' in many cases purchase the stocks of companies on the basis of investors' know and familiar as investors' have more information about companies and their stocks and take it as easier to pursue the stock returns (Frieder and Subrahmanyam, 2005).

Finally, this study is performs the effect of trading experiences on financial behavior and attitudinal loyalty and satisfaction with company's performance. Investment gain results in more positive financial behavior and experience which leads to increment the investors' satisfaction and behavior loyalty and preference the base company over its competitor. Hence loss increases the negative financial behavior and experiences and decreases the satisfaction and behavior loyalty respectively. On the basis of findings of this study that the strongest variables are financial behavior towards feedback; familiarity towards satisfaction; education towards investors satisfaction and education with preferences over competitor. The study showing that major effect of Feedback, familiarity, investors' satisfaction and education are very important for trading stocks. The companies should focus on financial behavior and investors' satisfaction with regards of company's performance; all variables contribute to maximum variations on investors' satisfaction and financial behavior which are very high.

\section{Limitations}

- This study has studied few factors.

- Limitation of time period.

- This study was limited to Karachi and Karachi Stock Exchange it can be extended to other parts of stock market.

- This study was limited to investors; shareholders and brokers; other sectors could also be studied like stock market.

- This research was limited to positive experiences of investors.

- This study was limited to banking sectors of investors on financial behavior.

\section{Research Recommendations}

- There may be other factors that might be study like the role of brokers and institution actors in shareholders-investors financial decision making of stock trading.

- Overconfidence knowledge and miscalibration over stock experience.

- Future research direction could find the impact of brokers and institutions actor's suggestions and advices in investment decision of investors in stock trading.

- Future research is recommending that how affecting the company's performance to the investor's financial decision in stock trading.

- This study is directing the future research that effect of company performance in positive financial behavior of investors' decision. 
- The future research could study on positive path of coefficient of disappointment on positive financial decision of investment.

\section{References}

Lanlan Cao, et al., (2018), “The Effects of Search-Related and Purchase-Related Mobile App Additions on Retailers' Shareholder Wealth: The Roles of Firm Size, Product Category, and Customer Segment”, Journal of Retailing 94 (4, 2018) 343-351.

Humaira Asad, et al, (2018), "Behavioral Biases across the Stock Market Investors: Evidence from Pakistan”, Pakistan Economic and Social Review, Volume 56, No. 1 (summer 2018), pp. 185-209.

Shahid M. Naeem, et al., 2018, "Impact of Behavioral Biases on Investors Decision: Evidence from Pakistan", Journal of Organizational Behavioral Research, Cilt/Vol.: 3, Say1 / Is.: 2, Yil / Year: 2018.

Surajit S. et al., 2018, "Factors Affecting Investment Decision: A case Study on Bangladesh Stock Market", Journal of Accounting, Finance and Economics, Vol. 8. No. 2. June 2018 Issue. Pp. 1 - 19.

Mark KY Mak, et al., 2017, “An Exploratory Study of Investment Behavior of Investors”, International Journal of Engineering Business Management, Vol 9: 1-12, DOI:

$10.1177 / 1847979017711520$.

Betül Çal, Mary Lambkin, (2017) "Stock exchange brands as an influence on investor behavior", International Journal of Bank Marketing, Vol. 35 Issue: 3, pp.391-410, https://doi.org/10.1108/ IJBM-05-2016-0072.

Bagher Asgarnezhad N. et al., (2017) "Empirical analysis of the financial behavior of investors with brand approach (Case study: Tehran Stock Exchange)", Scientific Annals of Economics and Business, Vol. 64 (1), 2017, 97-121, DOI: 10.1515/saeb-2017-0007.

Hoffmann, Arvid O. I. et al., (2015) "How experiences with trading a company's stock Influence customer attitudes and purchasing behavior", International Journal of Bank Marketing, Vol. 33 Issue: 7, pp.963-992, https://doi.org/10.1108/IJBM-11-2014-0163.

Marten Risius, et al., "Differential Emotions and the Stock Market, The Case of Companyspecific Trading", (2015). ECIS, 2015 Completed Research Papers. Paper 147. ISBN 978-300-050284-2, http://aisel.aisnet.org/ecis2015 cr/147.

Krutika Mistry, (2015), “A Study of Investors' Behavior in Stock Market- With Special Reference to Indian Stock Market", International Journal of Management and Commerce Innovations ISSN 2348-7585 (Online), Vol. 3, Issue 1, pp: (541-545). 
Willaby, H.W., et al. (2015), "Testing complex models with small sample sizes: a historical overview and empirical demonstration of what partial least squares (PLS) can offer differential psychology", Personality and Individual Differences, Vol. 84, pp. 73-78.

Khoa Cuong P. et al., (2014), “Factors Influencing Investors' Behavior: An Empirical Study of the Vietnamese Stock Market", American Journal of Business and Management, Vol. 3, No. 2, 2014, 77-94, DOI: 10.11634/216796061403527.

Asab M. Zulqarnain, et al., 2014, "Impact of Behavioral Finance and Traditional Finance on Financial Decision Making Process", Journal of Economics and Sustainable Development, ISSN 2222-1700 (Paper) ISSN 2222-2855 (Online), Vol.5, No.18, 2014.

Rakesh, H.M. (2014, “A study on individual investors' behavior in stock markets of India”, International Journal in Management and Social Science, 2(2), 165-174.

Henseler, J. et al. (2014), "Common beliefs and reality about partial least squares: comments on Rönkkö and Evermann (2013)”, Organizational Research Methods, Vol. 17

No. 2, pp. 182-209.

Aspara, J. (2013), "The role of product and brand perceptions in stock investing: effects on investment considerations, optimism and confidence", Journal of Behavioral Finance, Vol. 14 No. 3, pp. 195-212.

Islam, S. (2012), "Behavioral Finance of an Inefficient market”, Global Journal of Management and Business Research, 12(14).

Babajide, A. A. et al. (2012). Investors' Behavioral Biases and The Security Market: An Empirical Study of the Nigerian Security Market. Accounting and Finance Research, 1,1.

Hair J.F. et al. (2011), "PLS-SEM: indeed a silver bullet", The Journal of Marketing Theory and Practice, Vol. 19 No. 2, pp. 139-152.

Lin, H.W. (2011), "Elucidating rational investment decisions and behavioral biases:

Evidence from the Taiwanese Stock Market", African Journal of Business Management, 5(5), 1630.

Henseler, J. and Chin, W.W. (2010), “A comparison of approaches for the analysis of interaction effects between latent variables using partial least squares path modeling", Structural Equation Modeling, Vol. 17 No. 1, pp. 82-109.

Aspara, J. (2009), "Stock ownership as a motivation of brand loyal and brand-supportive behaviors", Journal of Consumer Marketing, Vol. 26 No. 6, pp. 427-436.

Wetzels, M. et al. (2009), "Using PLS path modeling for assessing hierarchical construct models: guidelines and empirical illustration”, MIS Quarterly, Vol. 33 No. 1, pp. 177-195.

Reinartz W.J. et al. (2009), "An empirical comparison of the efficacy of covariance-based and variance-based SEM", International Journal of Research in Marketing, Vol. 26 No. 4, pp. 332-344. 
Rita Martenson, (2008) "How financial advisors affect behavioral loyalty", International Journal of Bank Marketing, Vol. 26 Issue: 2, pp.119-147, https://doi.org/10.1108/02652320810852781.

Naime Usul, O. O. et al., (2008) "Affect-based stock investment decision: The role of affective self-affinity", Journal of Behavioral and Experimental Economics 68 (2017) 97109.

Barber B.M et al., (2008), "All that glitters: the effect of attention and news on the buying behavior of individual and institutional investors", Review of financial studies, vol. 21 No. 2 , pp. 785-818.

Doya K. (2008), "Modulators of decision making”, Nature neuroscience, 11(14), 410-16.

Malcolm Baker and Jeffrey Wurgler, (2007), "Investor Sentiment in the Stock Market", Journal of Economic Perspectives_-Volume 21, Number 2-spring 2007.

Ringle, C.M., et al. (2005), SmartPLS 2.0 (M3) Beta, SmartPLS, Hamburg.

Tenenhaus, M., et al. (2005), "PLS path modeling”, Computational Statistics and Data Analysis, Vol. 48 No. 1, pp. 159-205.

Frieder, L. and Subrahmanyam, A. (2005), "Brand perceptions and the market for common stock", Journal of Financial and Quantitative Analysis, Vol. 40 No. 1, pp. 57-85.

Heskett, J.L. (2002), “Beyond customer loyalty”, Managing Service Quality, Vol. 12 No. 6, pp. 355-357.

Shefrin H. (2001), "Do investors expect higher returns from safer stocks than from riskier stocks", The Journal of Psychology and Financial Market, Vol. 2 No. 4, pp. 176-181.

Hulland, J. (1999), "Use of partial least squares (PLS) in strategic management research: a review of four recent studies", Strategic Management Journal, Vol. 20 No. 2, pp. 195-204.

Chin, W.W. (1998), “Commentary: issues and opinion on structural equation modeling”, MIS Quarterly, Vol. 22 No. 1, pp. 7-16.

Cohen, J. (1988), Statistical Power Analysis for the Behavioral Sciences, Erlbaum, Hillsdale, NJ.

Baron, R.M. and Kenny, D.A. (1986), "The moderator-mediator variable distinction in social psychological research: conceptual, strategic, and statistical considerations”, Journal of

Personality and Social Psychology, Vol. 51 No. 6, p. 1173.

Shefrin, H. et al. (1985), "The disposition to sell winners too early and ride losers too long: theory and evidence", Journal of Finance, vol. 40 No. 3, pp. 777-790.

Fornell, C.G. and Bookstein, F.L. (1982), "Two structural equation models: LISREL and PLS applied to consumer exit-voice theory”, Journal ofMarketing Research, Vol. 19 No. 4, pp. 440-452. 
Fornell, C. and Larcker, D.F. (1981), "Evaluating structural equation models with unobservable variables and measurement error", Journal of Marketing Research, Vol. 18 No. 1 , pp. 39-50. 